\title{
Phenotypic characterisation of Human Immunodeficiency Virus type 1 Envelope entry efficiency of transmitted/founder variants circulating in Mbeya, Tanzania
}

\author{
Andile Nofemela ${ }^{a}$, Philippe Selhorst ${ }^{a}$, Gama Bandawe ${ }^{a}$, Jinny Marais ${ }^{a}$, Leonard Maboko ${ }^{d}$, \\ Michael Hoelscher $^{\mathrm{d}, \mathrm{e}}$, Carolyn Williamson ${ }^{\mathrm{a}, \mathrm{b}}$, Zenda Woodman $^{\mathrm{c} *}$ \\ ${ }^{a}$ Institute of Infectious Disease and Molecular Medicine, and Division of Medical Virology, Faculty \\ of Health Sciences, University of Cape Town, Cape Town, South Africa. \\ ${ }^{\mathrm{b}}$ National Health Laboratory Services, Groote Schuur Hospital, Anzio Rd, Observatory, Cape Town, \\ South Africa \\ ${ }^{\mathrm{c}}$ Department of Molecular and Cell Biology, University of Cape Town, \\ Rondebosch, Cape Town, South Africa. \\ ${ }^{\mathrm{d}}$ National Institute for Medical Research - Mbeya Medical Research Centre, Mbeya, Tanzania \\ ${ }^{\mathrm{e}}$ Department for Infectious Diseases and Tropical Medicine, Klinikum of the \\ University of Munich, Munich, Germany. \\ *Corresponding author: \\ Mailing address: Department of Molecular and Cell Biology, University of Cape Town, Rondebosch, \\ Cape Town, South Africa. Phone: +27- 21- 650-2404. Fax: +27- 21- 650-1861: E-mail: \\ zl.woodman@uct.ac.za
}

\begin{abstract}
Background: Altered fitness of transmitted founder (T/F) HIV-1 variants has been linked to slowed disease progression, yet almost all of these studies have focussed on the role of attenuating immune escape mutations in T/F Gag or entry efficiency of Envelope (Env) in long-term non-progressors (LTNP) and elite suppressors (ES) during chronic stages of infection. As Env could also play an important role in viral fitness during early infection, we investigated if T/F Env entry efficiency, prior to immune selection, affected viral loads of progressors in vivo.
\end{abstract}

Findings: Functional Env clones from eight progressors and one LTNP, representing the T/F virus responsible for clinical infection, were constructed. Subsequently Env pseudoviruses (PSVs) were generated and confirmed to be all R5 but not macrophage-tropic. PSVs had a $\sim 80$ fold range in entry efficiencies using TZM-bl cells with the LTNP being the poorest enterer. Enhanced entry was associated with increased viral load at 3 months although this association was reduced by 12 months. Finally, we show that entry efficiency was influenced by fusion capacity, CCR5/CD4 dependency, and/or incorporation of gp120 into pseudovirions.

Conclusion: The variation in TZM-bl entry efficiency of T/F viruses was due to one or more advantageous Env attributes. Viruses with high entry efficiency may have a replication advantage subsequent to transmission, leading to increased viral loads during early infection of progressors.

Keywords: HIV, transmission, entry efficiency, Mbeya, Tanzania 


\subsection{Introduction}

HIV transmission is associated with a severe genetic bottleneck where usually only one virus survives to establish clinical infection (Abrahams et al., 2009; Keele et al., 2008; Haaland et al., 2009; Nofemela et al., 2011). Low viral fitness of these transmitted founder (T/F) viruses has been linked to slower disease progression (Martinez-Picado et al., 2006; Goepfert et al., 2008; Chopera et al., 2009; Song et al., 2012; Prince et al., 2012; Yue et al. 2015) which is of significance to vaccine design as an attenuated $\mathrm{T} / \mathrm{F}$ might provide long-term viral control. However, most of these studies have focussed on Gag Cytotoxic T cell (CTL) escape mutations that attenuate viral replication, and no studies have investigated whether entry efficiency of T/Fs could also influence disease progression. However, Env also plays a major role in the competitive and adaptive ability of the virus (Rangel et al., 2003; Travers et al., 2005) and entry efficiency has been shown to be a determinant of overall viral fitness (Ball et al., 2003; Marozsan et al., 2005) and disease progression (Lassen et al., 2009; Casado et $a l .$, 2013). The influence of entry efficiency on disease progression has been limited to the study of long-term non-progressors (LTNP) and elite suppressors (ES) which showed that these individuals carried viruses in the chronic stage of infection with lower Env entry efficiency compared to progressors (Lassen et al., 2009; Casado et al., 2013). Furthermore, while there have been several studies characterizing the properties of transmitted viruses (Ochsenbauer et al., 2012; Ping et al., 2013; Salazar-Gonzalez et al., 2009), there is limited information on the association between Env phenotypic properties of $\mathrm{T} / \mathrm{F}$ variants and disease progression. Therefore, this study aimed to determine whether $\mathrm{T} / \mathrm{F}$ entry efficiency as a function of viral fitness could influence viral loads of progressors, and to understand better the underlying role of other phenotypic properties of $\mathrm{T} / \mathrm{F}$ viruses, such as tropism, CCR5 and CD4 dependency, fusion capacity and Env incorporation.

\subsection{Methods \\ 2.1 Cohort description}

The HIV Superinfection Study (HISIS) highrisk cohort from Mbeya, Tanzania recruited drug-naive participants within three months of their previous HIV-negative sample (Herbinger et al., 2006; Riedner et al., 2006). Analysis of 212 Env sequences from 22 participants $(\mathrm{n}=10$ sequences per participant) generated using single genome amplification (SGA) indicated that sixteen participants were infected with a single infectious unit at transmission (Nofemela et al., 2011). Neighbour-joining trees and HIGHLIGHTER plots

http://www.hiv.lanl.gov) of the SGA sequences were used to identify the sequence of the T/F virus, and the amplicons identical to the consensus sequence were cloned from nine acute stage participants as part of the Vaccine Immune Monitoring Consortium, Collaboration for AIDS Vaccine Discovery (VIMC - CAVD) (http://www. cavd.org). Analysis of longitudinal viral loads indicated that eight of the participants were progressors, and one was an LTNP based on classification by Casado et al., (2010).

\subsection{PCR amplification and cloning of the env gene.}

The PCR amplification of the HIV-1 env gene was done using the SGA approach previously described (Abrahams et al., 2009; Keele et al., 2008). The second round PCR reaction was repeated using the high fidelity Phusion Hot Start DNA Polymerase (Finnzymes), together with, $0.2 \mathrm{mM}$ dNTPs (Roche), $4 \mu \mathrm{M}$ of Env 1A-Rx (5' CAC CGG CTT AGG CAT CTC CTA TAG CAG GAA GAA 3') and EnvN (5' CTG CCA ATC AGG GAA AGT AGC CTT GT 3') in a final volume $50 \mu \mathrm{l}$. The cycling conditions for this reaction were as follows: denaturing at $94{ }^{\circ} \mathrm{C}$ for 5 minutes, 45 cycles of $94{ }^{\circ} \mathrm{C}$ for 30 seconds; $55^{\circ} \mathrm{C}$ for 30 seconds; $72{ }^{\circ} \mathrm{C}$ for 4 minutes, and a final extension step at $72{ }^{\circ} \mathrm{C}$ for 10 minutes. The amplicons were gel purified and cloned into the mammalian 
expression vectorspcDNA3.1D/V5-HisTOPO (Invitr ogen) or pTarget (Promega, US) according to the manufacturer's instructions. Functional Env clones were selected using a 96-well plate format pseudovirion entry efficiency assay based on relative light units (RLU) that are 2.5 times above background.

\subsection{Pseudovirion entry efficiency assays}

Pseudoviruses were generated by cotransfection of HEK 293T cells with $2.5 \mu \mathrm{g}$ $e n v$ and $5 \mu \mathrm{g}$ of either the subtype B HIV-1 backbone pSG3.1 $e_{e n v}$ (a gift from $\mathrm{L}$. Morris, NICD) or the subtype $\mathrm{C}$ backbone pBR264F-Mlusenv (a gift from B. Hahn, UAB) using PolyFect Transfection Reagent (QIAGEN). After 48 hours, the viral supernatant $(2 \mathrm{ml})$ was harvested and clarified through a $0.45 \mu \mathrm{m}$ filter and stored at $-80^{\circ} \mathrm{C}$. Pseudovirus titer was normalized using p24 ELISA (Vironostika HIV-1 Antigen microelisa system, Biomerieux, FRA) according to the manufacturer's instructions. TZM-bl cells $\left(1 \mathrm{X} \quad 10^{4}\right.$ cells) were infected in triplicate with $50 \mathrm{ng}$ p24 of pseudovirus for 48 hours before the medium was removed, and cells were lysed with Bright-Glo buffer (Promega, US). Luciferase activity (RLU) was measured using a Glomax 96-well microplate luminometer (Promega, US). The functional subtype C clone, Du151a, an R5 tropic T/F variant with high similarity to subtype $\mathrm{C}$ consensus sequence was used as a positive control (Williamson et al., 2003; Burgers et al., 2006) and included in all experiments so that clonal Env entry efficiency could be measured as a percentage relative to DU151a to control for inter-experimental variation. Pseudovirion stock generated by the transfection of the pSG3.1 $\Delta e n v$ backbone was used as a negative control, and the RLU reading of cells only was considered as background signal. A RLU reading of 2.5 times above background was considered a positive infection measurement based on the TCID50 methodology of Reed and Meunch (Fouda et al., 2013).

\subsection{Coreceptor phenotype}

Pseudoviruses were generated by cotransfecting Env clones with the luciferaseencoding pNL4-lucR ${ }^{-}{ }^{-}$backbone (NIH Aids Reagent Programme). U87 cell lines that express CD4, and either CCR5 or CXCR4 coreceptor were infected with $50 \mathrm{ng}$ p24 of virus and luciferase activity was measured after 48 hours. Viruses that were able to infect the U87 - CD4 - CCR5 cells were classified as R5 tropic, and viruses that infected U87 - CD4 - CXCR4 were classified as X4-tropic. The Env clones QHO (Li et al., 2005), RPI (Cilliers et al., 2005), and Du179 (van Harmelen et al., 2001) were obtained from P. Moore (NICD), and were used as positive controls for R5-, X4-, and dual-tropic R5X4 variants, respectively. A pseudovirion stock generated with the transfection of the pNL4-lucR $\mathrm{E}^{-}$backbone was used as a negative control

\subsection{Pseudovirus entry inhibition assay}

TZM-bl cells $\left(1 \mathrm{X}^{4} 0^{4}\right.$ cells per well) were infected in triplicate with pseudovirus (50 ng p24) in the presence of increasing concentration of TAK779 $(0.04-400 \mathrm{nM})$ and $\mathrm{T}-20 \quad(0.3-25 \mu \mathrm{g} / \mathrm{ml}) \quad(\mathrm{NIH}$ Aids Reagent Programme), and luciferase activity was measured after 48 hours, and the IC50 was determined using GraphPad Prism software 5 (CA, USA). Soluble CD4 IC50 was measured as part of the VIMC-CAVD ( http://www.cavd.org) study and included in this analysis.

\subsection{Cell-cell fusion assay}

HEK 293 T cells $\left(4 \times 10^{5}\right)$ were seeded in 6well plates overnight, and co-transfected with $3.75 \mu \mathrm{g}$ of each individual env plasmid and $3.75 \mu \mathrm{g}$ of pSVtat72 (NIH AIDS Reagent Programme) for 48 hours using the PolyFect Transfection Reagent (QIAGEN, US) according to the manufacturer's instructions. The cell medium was removed, and the cells were lifted using 0.04\% EDTA. The 293 T cells $\left(1 \times 10^{4}\right.$ cells per well) were added to TZM-bl cells $\left(1 \times 10^{4}\right.$ cells per well) and allowed to incubate at $37^{\circ} \mathrm{C}$ for 24 hours. The media $(100 \mu \mathrm{l})$ was removed from the cells, and $100 \mu \mathrm{l}$ of Bright-Glo buffer (Promega, US) was added. The plate 
was incubated for 2 minutes at room temperature with gentle shaking. After cell lysis, $150 \mu \mathrm{l}$ was transferred to a Co-Star black plate, and the plate was read immediately using a Glomax 96 microplate luminometer (Promega, US). The percentage fusion capacity was measured relative to the reference clone, Du151a.

\subsection{Pseudovirion infection of Affinofile cells.}

Pseudoviruses were generated by cotransfecting HEK 293T cells with $5 \mu \mathrm{g}$ of env clone and $10 \mu \mathrm{g}$ of the luciferaseencoding pNL4-lucR ${ }^{-}$backbone (NIH Aids Reagent Programme). Pseudoviruscontaining cell culture medium was collected after 48 hours, and filtered $(0.45 \mu \mathrm{M})$ before p24 levels were measured (Vironostika HIV1 Antigen microelisa system, Biomerieux, FRA). The Affinofile cell lines, a generous donation from B. Lee (UCLA), were induced and infected as previously described by Lassen et al., (2009) and colleagues. Briefly, the 293 Affinofile cells $\left(1 \times 10^{4}\right.$ cells per well) were seeded in 24-well plates, and induced with a concentration range of minocyline $(0-5 \mathrm{ng} / \mathrm{ml})$ and ponasterone A $(0-4 \mu \mathrm{M})$ to induce CD4 and CCR5 expression, respectively. The cells were collected after 24 hours and washed with PBS before staining. The cells were stained with PE anti-human CD4 and PE anti-human CD195 (CCR5) (BioLegend, US) for 30 minutes at room temperature. The absolute number of CD4 and CCR5 was quantified using the Quanibrite beads (BD Biosciences, US) according to the manufacturer's instructions. The data acquisition and flow cytometry analysis was done using Cellquest and Flowjo software, respectively.

Affinofile cells ( 1 X $10^{4}$ cells per well) were seeded in a 96-well plate for 48 hours, and were induced with minocyline $(2.5-5$ $\mathrm{ng} / \mathrm{ml})$ and ponasterone $\mathrm{A}(2-4 \mu \mathrm{M})$ for 24 hours. The cells were then infected with 100 ng p24 pseudovirus and infection was determined after $48 \mathrm{hrs}$ using luminescence. Entry efficiency in 293Affinofile cells was determined based on RLU readings. CCR5 dependence (percentage infection relative to high CD4/high CCR5) was determined using the following equation: RLU (high CD4/low CCR5)/RLU (high CD4/high CCR5) X 100 (Ping et al., 2013).

\subsection{Pseudovirus Env Western Blotting}

Pseudoviral stocks were generated by cotransfecting HEK 293 T cells $\left(2 \times 10^{6}\right.$ cells) with $5 \mu \mathrm{g}$ of cloned $e n v$ and $10 \mu \mathrm{g}$ of the subtype B HIV-1 backbone pSG3.1Aenv. After 48 hours, the clarified culture medium was centrifuged at $26000 \mathrm{rpm}$ for 2 hours through a $20 \%$ glycerol cushion at $4^{\circ} \mathrm{C}$ in an RW55 rotor (Beckman Coulter, GER) to harvest pseudovirus. The viral pellet was resuspended in PBS for p24 determination and viral quantitation using the Vironostika HIV-1 Antigen microelisa system (Biomerieux, FRA) before viral lysis in SDS Laemelli loading buffer $[40 \mathrm{mM}$ Tri-HCL $(\mathrm{pH} \quad 6.8), \quad 10 \%$ glycerol, $10 \% \quad \beta$ mercaptethanol, and $1 \%$ SDS]. The equivalent amount $(1.5 \mathrm{ug})$ of total p24 pseudoviral lysate was resolved using $10 \%$ SDS-PAGE before transfer to nitrocellulose membrane. The primary antibodies (sheep anti-gp120 and rabbit ARP 432) raised against gp120 and p24, respectively were obtained from the NIH AIDS Reagent Programme. Primary antibodies for gp120 and p24 were detected with horseradish peroxidase-conjugated goat-anti-sheep IgG (Sigma, US) and alkaline phosphataseconjugated goat anti-rabbit IgG (Sigma, US) secondary antibodies respectively. The gp120 Western blot was detected using the LumiGlo chemiluminescent substrate (KPL) and exposed to X-ray film, and the p24 Western Blot was visualised with NCIP/BCIP tablets (Roche, GER).

\subsection{Statistical analysis}

The association of entry efficiency with viral load, IC50 measurements and fusion capacity was calculated using the Spearman correlation test. These figures were constructed using GraphPad Prism 5 software (CA, USA). 
Table 1. Description of transmitted/founder Env clones from a high-risk opulation of female bar workers from Mbeya, Tanzania

\begin{tabular}{|c|c|c|c|c|c|c|c|c|c|c|}
\hline Clone ID & $\begin{array}{l}\text { Time } \\
\text { post- } \\
\text { infection } \\
\text { (Days) }\end{array}$ & $\begin{array}{l}\text { Sub } \\
\text { type }\end{array}$ & $\begin{array}{l}\text { Fiebig } \\
\text { Staging }\end{array}$ & $\begin{array}{l}\text { Entry } \\
\text { efficiency } \\
\text { (\% } \\
\text { infection } \\
\text { relative to } \\
\text { Du151a) }\end{array}$ & $\begin{array}{l}\text { Viral } \\
\text { Load at } 3 \\
\text { months } \\
\text { Post- } \\
\text { infection } \\
\text { (copies/ml) }\end{array}$ & $\begin{array}{l}\text { Viral Load } \\
\text { at } 12 \\
\text { months } \\
\text { Post- } \\
\text { infection } \\
\text { (copies/ml) }\end{array}$ & $\begin{array}{l}\text { Cell } \\
\text { Tropi } \\
\text { sm }\end{array}$ & $\begin{array}{l}\text { Soluble } \\
\text { CD4 } \\
\text { IC50 } \\
(\mathrm{nM})\end{array}$ & $\begin{array}{l}\text { TAK779 } \\
\text { IC50 } \\
(\mathrm{nM})\end{array}$ & $\begin{array}{l}\text { T-20 } \\
\text { IC50 } \\
(\mathrm{nM})\end{array}$ \\
\hline 390T/FTZ & 45 & $\mathrm{C}$ & V & 159.6 & $>750000$ & $>750000$ & R5 & 2.50 & 21.28 & 414 \\
\hline 89T/FTZ & 14 & $\mathrm{CD}$ & $\mathrm{I} / \mathrm{II}$ & 121.4 & $>750000$ & 322000 & R5 & 48 & 9.84 & 258 \\
\hline 216T/FTZ & 14 & $\mathrm{C}$ & VI & 80.0 & $>750000$ & 914 & $\mathrm{R} 5$ & $>1087$ & 125.50 & 537 \\
\hline $605 \mathrm{~T} / \mathrm{FTZ}$ & 41 & $\mathrm{AC}$ & V/VI & 63.5 & 434000 & $>750000$ & $\mathrm{R} 5$ & 161 & 20.32 & 166 \\
\hline $401 \mathrm{~T} / \mathrm{FTZ}$ & 45 & $\mathrm{CD}$ & ND & 52.4 & 51500 & 56600 & $\mathrm{R} 5$ & 217 & 60.77 & 300 \\
\hline $234 \mathrm{~T} / \mathrm{FTZ}$ & 45 & $\mathrm{C}$ & V/VI & 17.7 & 509000 & 71400 & R5 & 117 & 101.33 & 318 \\
\hline $569 \mathrm{~T} / \mathrm{FTZ}$ & 45 & $\mathrm{C}$ & V/VI & 15.9 & 23800 & 6060 & $\mathrm{R} 5$ & 313 & 42.94 & 735 \\
\hline $346 \mathrm{~T} / \mathrm{FTZ}$ & 41 & $\mathrm{C}$ & VI & 4.8 & 26700 & 22700 & R5 & 34 & 33.63 & 1215 \\
\hline 398T/FTZ & 45 & $\mathrm{C}$ & ND & 2.0 & 2378 & 1070 & $\mathrm{R} 5$ & 356 & 8.18 & $\begin{array}{l}>556 \\
4\end{array}$ \\
\hline
\end{tabular}

The T/F Env clones characterized in this study were generated from samples at Fiebig stages I/II to VI. The plasma viral loads at the time of sampling ranged from 2378 to $>750000$ copies $/ \mathrm{ml}$

$>750000$ was the maximum detection limit of the assay

>1087: Resistant to $1087 \mathrm{nM}$ sCD4; >5564 nM: Resistant to $5564 \mathrm{nM} \mathrm{T-20.}$

TZM-bl cells ( 1 X $10^{4}$ cells per well) were infected in triplicate with $50 \mathrm{ng}$ p24 of pseudovirus (PSV) in the presence of a serial dilution of inhibitor and it's IC50 was determined using GraphPad Prism software 5 (CA, USA).

* Clone identification: participant number_transmitted/founder_country of origin Env clones with high entry efficiency are highlighted in bold.

Clone 398 is classified as a long-term non-progressor (LTNP) due to plasma HIV RNA levels that are equal to or below 2000 copies/ml for $\sim 4$ years without antiretroviral therapy. 
A

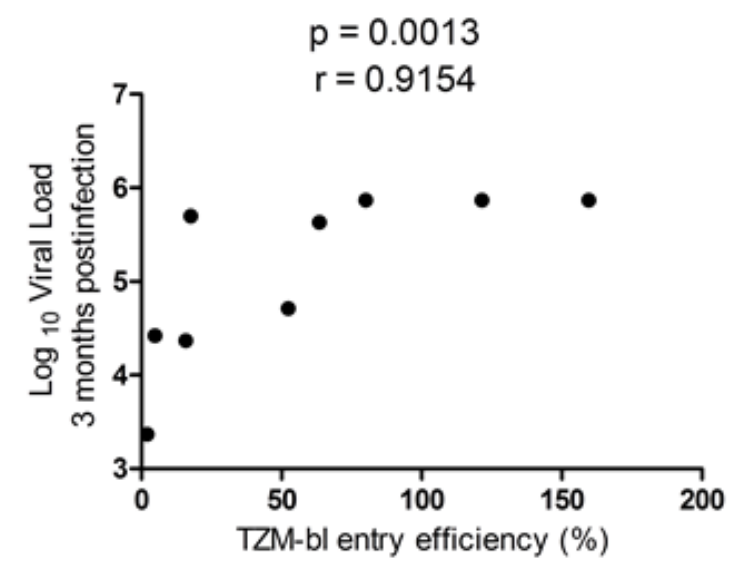

B

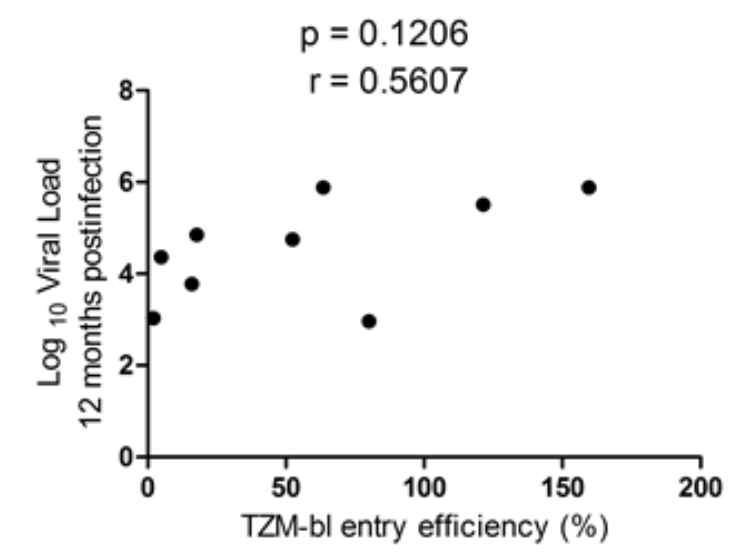

Figure 1. Association between Env entry efficiency of T/F variants and viral load

Pseudovirions were generated using the Subtype B backbone pSG3.1 $\Delta e n v$ and entry efficiency was measured relative to Du151a (\%). The association between relative infectivity in TZM-bl cells and viral load at 3 (A) and 12 (B) months post-infection was analyzed using a Spearman correlation test.

\subsection{Results}

Functional Env clones were constructed from nine participants infected with either HIV-1 subtype $\mathrm{C}(\mathrm{n}=6)$ or recombinant $\mathrm{CD}(\mathrm{n}=2)$ or $\mathrm{AD}(\mathrm{n}=1)$ who were previously found to be infected with a single variant (Nofemela et al., 2011). All clones were identical to the consensus of the SGA-derived env amplicons, and assumed to represent the $\mathrm{T} / \mathrm{F}$ virus responsible for clinical infection (Keele et al., 2008). Pseudovirions (PSVs) were generated to determine the effect of entry efficiency on viral load and to identify phenotypic properties that could influence this relationship. The only LTNP of this study had the lowest entry efficiency supporting the two previous studies that showed that viruses from HIV LTNP and ES had lower entry efficiency compared to chronic progressors (Lassen et al., 2009; Casado et $a l ., 2013)$. We thus wanted to determine the impact of entry efficiency of T/F PSVs on viral loads from progressors subsequent to transmission. We firstly wanted to determine the relationship between viral loads and entry efficiency of progressors only and thus excluded the LTNP from the analysis.

We found that PSV entry efficiency of TZM-bl cells was significantly associated with viral load at 3 months post-infection (mpi) $(\mathrm{p}=0.0072 ; \mathrm{r}=0.8783)$ but not at 12 mpi $(\mathrm{p}=0.1966 ; \mathrm{r}=0.5150)$. Our results were similar when we included the LTNP in the analysis (at 3mpi $\mathrm{p}=0.0013 ; \mathrm{r}=0.9154$ and at 12 mpi $\mathrm{p}=0.1206 ; \mathrm{r}=0.5607$ ) (Figure 1). The same trend was observed with PSVs generated using the subtype C backbone at both 3 mpi $(\mathrm{p}=0.0760 ; \mathrm{r}=$ $0.6272)$ and $12 \mathrm{mpi}(\mathrm{p}=0.0857 ; \mathrm{r}=0.6193)$ (data not shown). Overall, there was either a significant or a trend for an association between entry efficiency and viral loads, irrespective if the LTNP was included in the analysis or not.

Next we set out to identify whether coreceptor usage, CCR5/CD4 levels and fusion capacity contributed to the wide range of entry efficiencies observed for the PSVs. All the PSV clones only infected U87CD4+CCR5+ cells and not U87CD4+CXCR4+ cells, confirming R5 tropism 
A
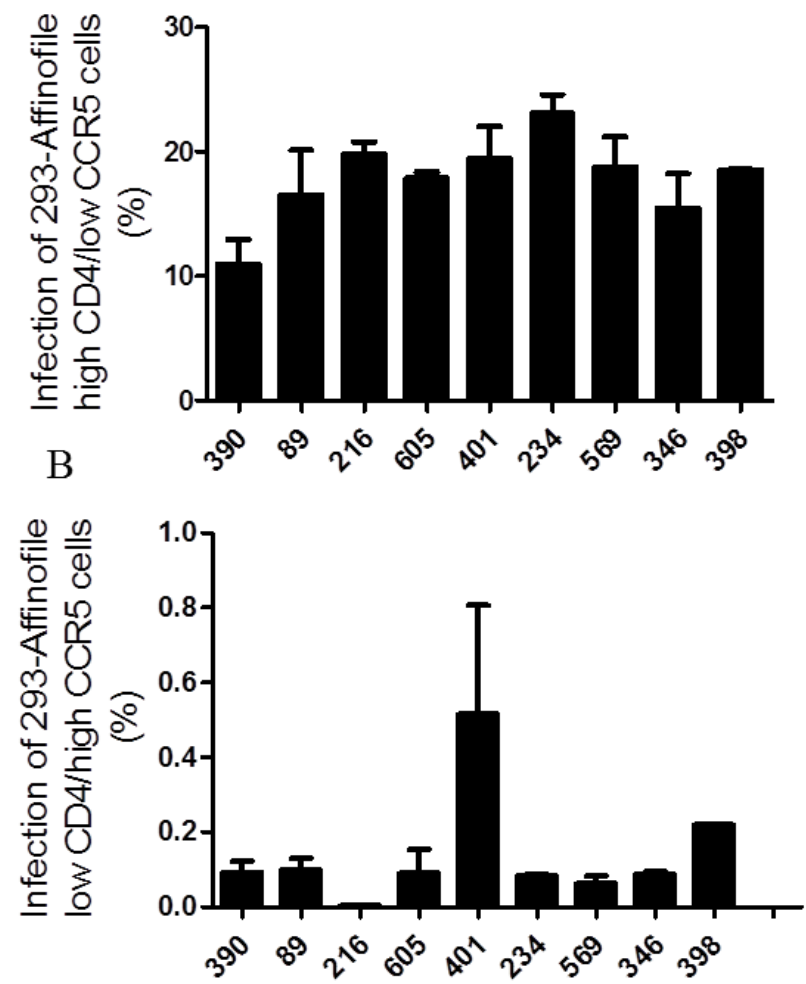

(Table 1). To assess the dependency of PSV entry on fusion, and CCR5 and CD4 levels, we first measured

Figure 2. Pseudovirion entry efficiency in dual-inducible HEK293-Affinofile cells at A) High CD4 and Low CCR5 levels and B) Low CD4 and High CCR5 levels. Entry efficiency is calculated as \% infection relative to entry of cells with $\mathrm{CD} 4^{\text {high }} / \mathrm{CCR} 5^{\text {high }}$ levels. This figure is a result of two independent experiments using two pseudovirus preparations, and the error bars represent the standard deviation between the two assays.

their sensitivity to entry inhibitors. A large range of inhibition could be observed for TAK779 $($ IC50 $=8.18-126.50 \mathrm{nM})$, T-20 $(\mathrm{IC} 50=166-5564 \mathrm{nM})$, and sCD4 (IC50 = 34 - $1087 \mathrm{nM}$ ). One PSV (clone 398) was resistant to T-20, and another (clone 216) was resistant to sCD4. However, there was no significant association between IC50 values and PSV entry efficiency in TZM-bl cells for any of these inhibitors. As a more direct measure to determine the impact of receptor levels on entry efficiency we also Copyright 2015 KEl Journals. All Rights Reserved used 293-Affinofile cells expressing either 1) high CD4 (146 397 molecules/cell) and low CCR5 (2 566 molecules/cell); or 2) low CD4 (2 397 molecules/cell) and high CCR5 (428 032 molecules/cell). All of the PSVs were able to infect when CCR5 levels were lowered to resemble that of $\mathrm{T}$ lymphocytes (\% infection relative to $\mathrm{CD} 4^{\text {high }} / \mathrm{CCR} 5^{\text {high }}$; median $=18.6 \% ;$ range $=10.9 \%-25 \%$ ) (Figure 2a). However, when CD4 receptor levels were lowered, and CCR5 levels remained high, resembling macrophages, 7/9 PSV clones did not enter, with the remaining two clones (398 and 401) entering at much lower levels $(\%$ infection relative to $\mathrm{CD} 4^{\text {high }} / \mathrm{CCR} 5^{\text {high }}$ of $0.21 \%$ and $0.51 \%$, respectively) (Figure 2b). Consistent with the lack of correlation with TAK779 sensitivity, the analysis revealed no association between entry in 293-Affinofile cells with high CD4/low CCR5 and entry in TZM-bl cells (p $=0.5517)$. In addition to measuring $\mathrm{T}-20$ sensitivity, we also performed a cell-cell fusion assay to assess fusion capacity of the PSVs. Again no statistically significant association could be observed between fusion and entry efficiency $(p=0.2298)$ (Figure 3). Finally, we measured Env incorporation into our PSV particles as this could play a role in entry efficiency (Bachrach et al., 2005). The relative position of gp120 of the PSV clones was determined relative to the gp120 positive control although bands representing gp160 and gp120 of clones 89 and 605 were incompletely resolved and thus not included in this analysis (Figure 4). The level of gp120 incorporation varied between the clones and for some of the PSVs there seemed to be an association between TZM-bl entry efficiency and the level of gp120 incorporation. PSV clones 234, 398 and 569 with relatively low TZM-bl entry efficiency (Table 1) had low gp120 incorporation and PSV clones with high entry efficiency (clones 390 and 216) had elevated relative levels of gp120 incorporation, suggesting that gp120 incorporation could be influencing TZM-bl entry efficiency (Figure 4). This apparent association was lost when 7| P a g e 
considering PSV clones 346 and 401, playing a role in the entry of these clones. suggesting that alternative factors could be
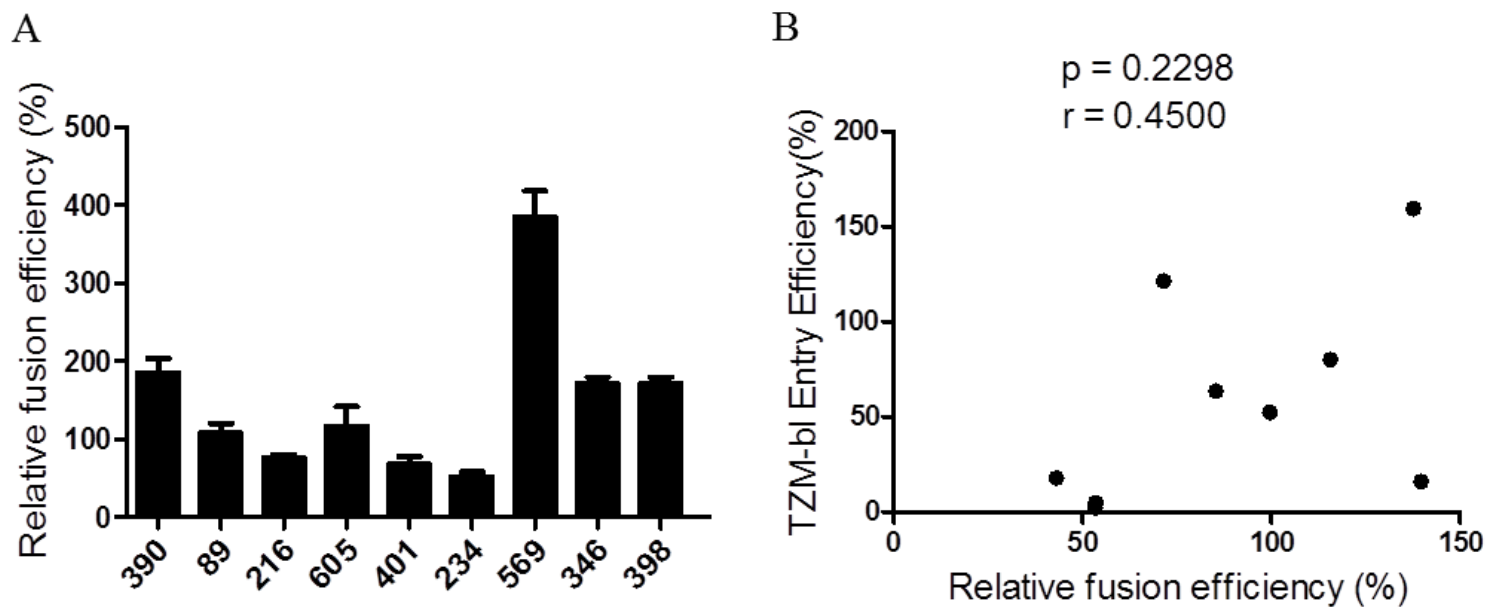

Figure 3. Cell-cell fusion capacity A) Env fusion capacity of the $T / F$ variants was determined using a cell-cell fusion assay and indicated as percentage fusion capacity relative to Du151a. The cell-cell fusion assay utilised HEK 293T cells $\left(4 \times 10^{5}\right)$ co-transfected with $3.75 \mu \mathrm{g}$ of each individual env plasmid and $3.75 \mu \mathrm{g}$ of pSVtat 72 for 48 hours before the cells were lifted and added to TZM-bl cells in a 1:1 ratio and relative light units (RLU) were measured. B) The association between relative fusion capacity and infectivity in TZM-bl cells was analysed using a Spearman correlation test.

\subsection{Discussion}

A few studies have shown a link between Env function and HIV replicative fitness (Kong et al., 2008; Rangel et al., 2003) and replicative fitness and disease progression (Quinones-Mateu et al., 200; Miura et al., 2010). In this study we report on high-risk women from Tanzania, recruited soon after infection, and show that the entry efficiency of $T / F$ Envelope PSVs was positively correlated with viral loads at 3 months, suggesting that entry efficiency of transmitted viruses could influence disease outcome during early infection. However, the relationship between viral loads and entry efficiency lost significance at $12 \mathrm{mpi}$, suggesting that other factors, such as immune responses, could be influencing the association during later stages of infection.

Overall, our results support the findings of Lassen et al., (2009) and Casado et al., (2013) who found that entry efficiency of viruses from seven ES and three LTNP, respectively were lower than those from chronic progressors, suggesting that viruses with poor entry could lead to viral control. In support, one of our PSV clones, 398, a LTNP with longitudinal viral loads below 2000

copies/ml (Casado et al., 2010) had the lowest entry efficiency. More importantly, we show that the effect of Env entry efficiency on disease progression is not restricted to ES and LTNP. Due to the overall relationship between Env function and viral loads, we wanted to identify the underlying biological factor(s) driving Env entry efficiency and thus potentially, replication fitness. As HIV replication fitness may be influenced by the level of CD4 and CCR5 at the surface of $\mathrm{T}$ cells (Poncelet et al., 1991), we investigated the effect of limiting host receptor levels on entry efficiency using Affinofile cells induced to express different levels of CD4 and CCR5. High levels of CD4 were shown to be 
important for entry of these pseudoviruses as low CD4 levels resulted in a marked reduction in entry compared to when CCR5 coreceptor numbers were lowered. The inability to mediate entry at low levels of
CD4 by most (7/9) pseudoviruses suggests that the $T / F$ viruses are unlikely to be macrophage-tropic, which supports findings in recent studies on subtype $\mathrm{B}$ and $\mathrm{C}$ viruses (Salazar-Gonzalez et al., 2009; Alexander et

\section{$\begin{array}{llllllllll}89 & 216 & 234 & 346 & 390 & 398 & 401 & 569 & 605 & \text {-ve +ve }\end{array}$}

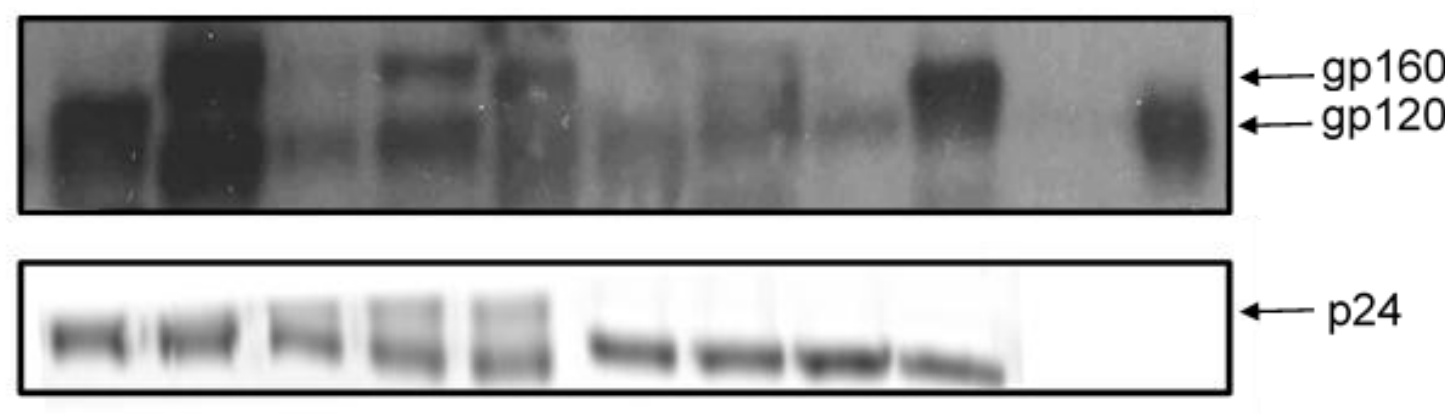

Figure 4. Pseudovirion incorporation of Env clones Pseudovirions were generated in HEK $293 \mathrm{~T}$ cells, and culture supernatants were layered over $20 \%$ glycerol and ultracentrifuged at $26000 \mathrm{rpm}$ for 2 hours. The pelleted viruses were lysed, and $1.5 \mathrm{ug}$ of p24 was loaded per lane. Negative control (-ve) comprises viral particles without envelope and the positive control is HIV-1 gp120 CM cat \#2968 (NIH AIDS Research and Reference Reagent Programme). The bottom panel indicates the amount of p24 loaded per lane. Clones with high entry efficiency are indicated in bold. The blot was probed with sheep anti-gp120 and rabbit ARP 432 raised against gp120 and p24, respectively (NIH AIDS Reagent Program, Division of AIDS, NIAID, NIH).

al., 2010; Ochsenbauer et al., 2012; Ping et al., 2013). Preliminary studies in our laboratory using IMCs also show that transmitted variants replicate well in PBMCs, but very poorly in macrophages (data not shown). In terms of cell-cell fusion, there was no correlation between entry efficiency and cell-cell fusion, despite some viruses with high entry efficiency having high cell-cell fusion capacity. This discrepancy could be due to the two assays measuring different parameters, with the pseudovirus assay being dependent on Env incorporation into viral particles, and the cell-cell fusion assay reliant on Env expression on the surface of cells.

As previous studies have shown that high levels of surface Env expression result in increased infectivity (Bachrah et al., 2005; Parker et al., 2012; Provine et al., 2009), we investigated whether the entry efficiency of the T/F Env clones was due to enhanced Env incorporation. This study found that incorporation of Env into pseudovirions may impact entry efficiency as some $\mathrm{T} / \mathrm{F}$ viruses with the highest entry efficiency had better gp120 incorporation compared to other

viruses. A recent study by Parrish et al., (2013) found that $T / F$ viruses are more infectious than chronic viruses, and this was partly due to the presence of higher number of Envelope particles on the surface. However, the relationship between Env incorporation and entry efficiency was not consistent for all the clones in this study, suggesting that other factors may be playing a role in the entry efficiency of the $T / F$ viruses.

\subsection{Conclusion}

In conclusion, high PSV entry efficiency was 
linked to higher viral loads during early infection, suggesting a possible role of $\mathrm{T} / \mathrm{F}$ Env entry efficiency in disease progression. Furthermore, as T/F Env fusion capacity, CCR5 and CD4 dependency, and Env incorporation influenced PSV entry efficiency, viruses with any one or more of these advantageous Env characteristics could replicate to higher titres that could in turn impact disease progression during early infection.

\subsection{Competing interests}

The authors declare that they have no competing interests.

\subsection{Author's contributions}

$\mathrm{AN}, \mathrm{CW}$, and $\mathrm{ZW}$ were involved in the conception and design of the study, and also the reviewing of the manuscript. PS was involved in data analysis and preparing the manuscript. GB, RT, JM performed some of the experiments. LM, MH co-ordinate the study cohort in Mbeya Tanzania, and are also involved in the acquisition of samples.

\subsection{References}

1. Abrahams, M. R., J. A. Anderson, E. E.Giorgi, C. Seoighe, K. Mlisana, L. H. Ping, G. S. Athreya, F. K. Treurnicht, B. F. Keele, N. Wood, J. F. Salazar-Gonzalez, T. Bhattacharya, H. Chu, I. Hoffman, S. Galvin, C. Mapanje, P. Kazembe, R. Thebus, S. Fiscus, W. Hide, M. S. Cohen, S. A. Karim, B. F. Haynes, G. M. Shaw, B. H. Hahn, B. T. Korber, R. Swanstrom, C. Williamson, C. A. I. S. Team and H. I. V. A. V. I. C. Center for (2009). "Quantitating the multiplicity of infection with human immunodeficiency virus type 1 subtype $\mathrm{C}$ reveals a non-poisson distribution of

\subsection{Acknowledgements}

The work is funded by the Collaboration for AIDS Vaccine Discovery (CAVD) as part of the Bill and Melinda Gates Foundation, Poliomyelitis Research Foundation, and the David and Elaine Potter Foundation. The clinical follow-up of this HIV Superinfection cohort was supported by a grant from the European Commission (DG XII, INCO-DC, ICA-CT-1999- 10007). The following reagents were obtained through the NIH AIDS Research and Reference Reagent Program, Division of AIDS, NIAID, NIH: pNL4-3.Luc. ${ }^{-}$. $^{-}$from Dr. Nathaniel Landau; HIV-1 gp120 Antiserum (PB1 Sub 2; Antiserum to HIV-1 p24 from Dr. Michael Phelan and HIV-1 gp120 CM Envelope protein (Cat \#2968).

We would like to thank the clinical staff of the NIMR - Mbeya Medical Research Programme and the participants of the HISIS cohort. We also would like to acknowledge Dr. Benhur Lee from UCLA for providing the 293-Affinofile cells, and also Mrs Desiree Bowers for her assistance with the FACS analysis.

transmitted variants." J Virol 83(8): 3556-3567.

2. Alexander, M., R. Lynch, J. Mulenga, S. Allen, C. A. Derdeyn and E. Hunter (2010). "Donor and recipient envs from heterosexual human immunodeficiency virus subtype $\mathrm{C}$ transmission pairs require high receptor levels for entry." J Virol 84(8): 4100-4104.

3. Bachrach, E., H. Dreja, Y. L. Lin, C. Mettling, V. Pinet, P. Corbeau and M. Piechaczyk (2005). "Effects of virion surface gp120 density on infection by HIV-1 and viral production by infected cells." Virology 332(1): 418-429. 
4. Ball, S. C., A. Abraha, K. R. Collins, A. J. Marozsan, H. Baird, M. E. Quinones-Mateu, A. Penn-Nicholson, M. Murray, N. Richard, M. Lobritz, P. A. Zimmerman, T. Kawamura, A. Blauvelt and E. J. Arts (2003). "Comparing the Ex Vivo Fitness of CCR5-Tropic Human Immunodeficiency Virus Type 1 Isolates of Subtypes B and C." Journal of Virology 77(2): 1021-1038.

5. Burgers, W. A., J. H. van Harmelen, E. Shephard, C. Adams, T. Mgwebi, W. Bourn, T. Hanke, A. L. Williamson and C. Williamson (2006). "Design and preclinical evaluation of a multigene human immunodeficiency virus type 1 subtype C DNA vaccine for clinical trial." J Gen Virol 87(Pt 2): 399-410.

6. Casado, C., S. Colombo, A. Rauch, R. Martinez, H. F. Gunthard, S. Garcia, C. Rodriguez, J. Del Romero, A. Telenti and C. Lopez-Galindez (2010). "Host and viral genetic correlates of clinical definitions of HIV-1 disease progression." PLoS One 5(6): e11079.

7. Casado, C., M. Pernas, V. Sandonis, T. Alvaro-Cifuentes, I. Olivares, R. Fuentes, L. Martinez-Prats, E. Grau, L. Ruiz, R. Delgado, C. Rodriguez, J. del Romero and C. Lopez-Galindez (2013). "Identification of a cluster of HIV-1 controllers infected with low replicating viruses." PLoS One 8(10): e77663.

8. Chopera, D. R., Z. Woodman, K. Mlisana, M. Mlotshwa, D. P. Martin, C. Seoighe, F. Treurnicht, D. A. de Rosa, W. Hide, S. A. Karim, C. M.
Gray, C. Williamson and C. S. Team (2008). "Transmission of HIV-1 CTL escape variants provides HLAmismatched recipients with a survival advantage." PLoS Pathog 4(3): e1000033.

9. Cilliers, T., P. Moore, M. Coetzer and L. Morris (2005). "In vitro generation of HIV type 1 subtype $\mathrm{C}$ isolates resistant to enfuvirtide." AIDS Res Hum Retroviruses 21(9): 776-783.

10. Fouda, G. G., T. Mahlokozera, J. F. Salazar-Gonzalez, M. G. Salazar, G. Learn, S. B. Kumar, S. M. Dennison, E. Russell, K. Rizzolo, F. Jaeger, F. Cai, N. A. Vandergrift, F. Gao, B. Hahn, G. M. Shaw, C. Ochsenbauer, R. Swanstrom, S. Meshnick, V. Mwapasa, L. Kalilani, S. Fiscus, D. Montefiori, B. Haynes, J. Kwiek, S. M. Alam and S. R. Permar (2013). "Postnatallytransmitted HIV-1 Envelope variants have similar neutralization-sensitivity and function to that of nontransmitted breast milk variants." Retrovirology 10: 3 .

11. G1 `oepfert, P. A., W. Lumm, P. Farmer, P. Matthews, A. Prendergast, J. M. Carlson, C. A. Derdeyn, J. Tang, R. A. Kaslow, A. Bansal, K. Yusim, D. Heckerman, J. Mulenga, S. Allen, P. J. Goulder and E. Hunter (2008). "Transmission of HIV-1 Gag immune escape mutations is associated with reduced viral load in linked recipients." J Exp Med 205(5): 1009-1017.

12. Haaland, R. E., P. A. Hawkins, J. Salazar-Gonzalez, A. Johnson, A. Tichacek, E. Karita, O. Manigart, J. Mulenga, B. F. Keele, G. M. Shaw, B. 
H. Hahn, S. A. Allen, C. A. Derdeyn and E. Hunter (2009). "Inflammatory genital infections mitigate a severe genetic bottleneck in heterosexual transmission of subtype A and C HIV1." PLoS Pathog 5(1): e1000274.

13. Herbinger, K. H., M. Gerhardt, S. Piyasirisilp, D. Mloka, M. A. Arroyo, O. Hoffmann, L. Maboko, D. L. Birx, D. Mmbando, F. E. McCutchan and M. Hoelscher (2006). "Frequency of HIV type 1 dual infection and HIV diversity: analysis of low-and high-risk populations in Mbeya Region, Tanzania." AIDS Res Hum Retroviruses 22(7): 599-606.

14. Keele, B. F., E. E. Giorgi, J. F. Salazar-Gonzalez, J. M. Decker, K. T. Pham, M. G. Salazar, C. Sun, T. Grayson, S. Wang, H. Li, X. Wei, C. Jiang, J. L. Kirchherr, F. Gao, J. A. Anderson, L. H. Ping, R. Swanstrom, G. D. Tomaras, W. A. Blattner, P. A. Goepfert, J. M. Kilby, M. S. Saag, E. L. Delwart, M. P. Busch, M. S. Cohen, D. C. Montefiori, B. F. Haynes, B. Gaschen, G. S. Athreya, H. Y. Lee, N. Wood, C. Seoighe, A. S. Perelson, T. Bhattacharya, B. T. Korber, B. H. Hahn and G. M. Shaw (2008). "Identification and characterization of transmitted and early founder virus envelopes in primary HIV-1 infection." Proc Natl Acad Sci U S A 105(21): 7552-7557.

15. Kong, X., J. T. West, H. Zhang, D. M. Shea, J. M'Soka $\mathrm{T}$ and C. Wood (2008). "The human immunodeficiency virus type 1 envelope confers higher rates of replicative fitness to perinatally transmitted viruses than to nontransmitted viruses." J Virol 82(23): 11609-11618.

16. Lassen, K. G., M. A. Lobritz, J. R. Bailey, S. Johnston, S. Nguyen, B. Lee, T. Chou, R. F. Siliciano, M. Markowitz and E. J. Arts (2009). "Elite suppressor-derived HIV-1 envelope glycoproteins exhibit reduced entry efficiency and kinetics." PLoS Pathog 5(4): e1000377.

17. Li, M., F. Gao, J. R. Mascola, L. Stamatatos, V. R. Polonis, M. Koutsoukos, G. Voss, P. Goepfert, P. Gilbert, K. M. Greene, M. Bilska, D. L. Kothe, J. F. Salazar-Gonzalez, X. Wei, J. M. Decker, B. H. Hahn and D. C. Montefiori (2005). "Human immunodeficiency virus type 1 env clones from acute and early subtype B infections for standardized assessments of vaccine-elicited neutralizing antibodies." J Virol 79(16): 1010810125.

18. Marozsan, A. J., D. M. Moore, M. A. Lobritz, E. Fraundorf, A. Abraha, J. D. Reeves and E. J. Arts (2005). "Differences in the fitness of two diverse wild-type human immunodeficiency virus type 1 isolates are related to the efficiency of cell binding and entry." J Virol 79(11): 7121-7134.

19. Martinez-Picado, J., J. G. Prado, E. E. Fry, K. Pfafferott, A. Leslie, S. Chetty, C. Thobakgale, I. Honeyborne, H. Crawford, P. Matthews, T. Pillay, C. Rousseau, J. I. Mullins, C. Brander, B. D. Walker, D. I. Stuart, P. Kiepiela and P. Goulder (2006). "Fitness cost of 
escape mutations in p24 Gag in association with control of human immunodeficiency virus type 1." J Virol 80(7): 3617-3623.

20. Miura, T., Z. L. Brumme, M. A. Brockman, P. Rosato, J. Sela, C. J. Brumme, F. Pereyra, D. E. Kaufmann, A. Trocha, B. L. Block, E. S. Daar, E. Connick, H. Jessen, A. D. Kelleher, E. Rosenberg, M. Markowitz, K. Schafer, F. Vaida, A. Iwamoto, S. Little and B. D. Walker (2010). "Impaired replication capacity of acute/early viruses in persons who become HIV controllers." J Virol 84(15): 75817591.

21. Nofemela, A., G. Bandawe, R. Thebus, J. Marais, N. Wood, O. Hoffmann, L. Maboko, M. Hoelscher, Z. Woodman and C. Williamson (2011). "Defining the human immunodeficiency virus type 1 transmission genetic bottleneck in a region with multiple circulating subtypes and recombinant forms." Virology 415(2): 107-113.

22. Ochsenbauer, C., T. G. Edmonds, H. Ding, B. F. Keele, J. Decker, M. G. Salazar, J. F. Salazar-Gonzalez, R. Shattock, B. F. Haynes, G. M. Shaw, B. H. Hahn and J. C. Kappes (2012). "Generation of transmitted/founder HIV-1 infectious molecular clones and characterization of their replication capacity in CD4 $\mathrm{T}$ lymphocytes and monocyte-derived macrophages." J Virol 86(5): 2715-2728.

23. Parker, Z. F., S. S. Iyer, C. B. Wilen, N. F. Parrish, K. C. Chikere, F. H. Lee, C. A. Didigu, R. Berro, P. J. Klasse, B. Lee, J. P. Moore, G. M. Shaw, B. H.
Hahn and R. W, Doms (2013). "Transmitted/founder and chronic HIV-1 envelope proteins are distinguished by differential utilization of CCR5." J Virol 87(5): 2401-2411.

24. Parrish, N. F., F. Gao, H. Li, E. E. Giorgi, H. J. Barbian, E. H. Parrish, L. Zajic, S. S. Iyer, J. M. Decker, A. Kumar, B. Hora, A. Berg, F. Cai, J. Hopper, T. N. Denny, H. Ding, C. Ochsenbauer, J. C. Kappes, R. P. Galimidi, A. P. West, Jr., P. J. Bjorkman, C. B. Wilen, R. W. Doms, M. O'Brien, N. Bhardwaj, P. Borrow, B. F. Haynes, M. Muldoon, J. P. Theiler, B. Korber, G. M. Shaw and B. H. Hahn (2013). "Phenotypic properties of transmitted founder HIV1." Proc Natl Acad Sci U S A 110(17): 6626-6633.

25. Ping, L. H., S. B. Joseph, J. A. Anderson, M. R. Abrahams, J. F. Salazar-Gonzalez, L. P. Kincer, F. K. Treurnicht, L. Arney, S. Ojeda, M. Zhang, J. Keys, E. L. Potter, H. Chu, P. Moore, M. G. Salazar, S. Iyer, C. Jabara, J. Kirchherr, C. Mapanje, N. Ngandu, C. Seoighe, I. Hoffman, F. Gao, Y. Tang, C. Labranche, B. Lee, A. Saville, M. Vermeulen, S. Fiscus, L. Morris, S. A. Karim, B. F. Haynes, G. M. Shaw, B. T. Korber, B. H. Hahn, M. S. Cohen, D. Montefiori, C. Williamson, R. Swanstrom, C. A.I. Study and H. I. V. A. V. I. C. the Center for (2013). "Comparison of viral Env proteins from acute and chronic infections with subtype $\mathrm{C}$ human immunodeficiency virus type 1 identifies differences in glycosylation and CCR5 utilization and suggests a 
new strategy for immunogen design." $\mathrm{J}$ Virol 87(13): 7218-7233.

26. Poncelet, P., G. Poinas, P. Corbeau, C. Devaux, N. Tubiana, N. Muloko, C. Tamalet, J. C. Chermann, F. Kourilsky and J. Sampol (1991). "Surface CD4 density remains constant on lymphocytes of HIV-infected patients in the progression of disease." Res Immunol 142(4): 291-298.

27. Prince, J. L., D. T. Claiborne, J. M. Carlson, M. Schaefer, T. Yu, S. Lahki, H. A. Prentice, L. Yue, S. A. Vishwanathan, W. Kilembe, P. Goepfert, M. A. Price, J. Gilmour, J. Mulenga, P. Farmer, C. A. Derdeyn, J. Tang, D. Heckerman, R. A. Kaslow, S. A. Allen and E. Hunter (2012). "Role of transmitted Gag CTL polymorphisms in defining replicative capacity and early HIV-1 pathogenesis." PLoS Pathog 8(11): e1003041.

28. Provine, N. M., W. B. Puryear, X. Wu, J. Overbaugh and N. L. Haigwood (2009). "The infectious molecular clone and pseudotyped virus models of human immunodeficiency virus type 1 exhibit significant differences in virion composition with only moderate differences in infectivity and inhibition sensitivity." J Virol 83(17): 9002-9007.

29. Quinones-Mateu, M. E., S. C. Ball, A. J. Marozsan, V. S. Torre, J. L. Albright, G. Vanham, G. van Der Groen, R. L. Colebunders and E. J. Arts (2000). "A dual infection/competition assay shows a correlation between ex vivo human immunodeficiency virus type 1 fitness and disease progression." J Virol 74(19): 9222-9233.

30. Rangel, H. R., J. Weber, B. Chakraborty, A. Gutierrez, M. L. Marotta, M. Mirza, P. Kiser, M. A. Martinez, J. A. Este and M. E. Quinones-Mateu (2003). "Role of the human immunodeficiency virus type 1 envelope gene in viral fitness." J Virol 77(16): 9069-9073.

31. Riedner, G., O. Hoffmann, M. Rusizoka, D. Mmbando, L. Maboko, H. Grosskurth, J. Todd, R. Hayes and M. Hoelscher (2006). "Decline in sexually transmitted infection prevalence and HIV incidence in female barworkers attending prevention and care services in Mbeya Region, Tanzania." AIDS 20(4): 609615.

32. Salazar-Gonzalez, J. F., M. G. Salazar, B. F. Keele, G. H. Learn, E. E. Giorgi, H. Li, J. M. Decker, S. Wang, J. Baalwa, M. H. Kraus, N. F. Parrish, K. S. Shaw, M. B. Guffey, K. J. Bar, K. L. Davis, C. Ochsenbauer-Jambor, J. C. Kappes, M. S. Saag, M. S. Cohen, J. Mulenga, C. A. Derdeyn, S. Allen, E. Hunter, M. Markowitz, P. Hraber, A. S. Perelson, T. Bhattacharya, B. F. Haynes, B. T. Korber, B. H. Hahn and G. M. Shaw (2009). "Genetic identity, biological phenotype, and evolutionary pathways of transmitted/founder viruses in acute and early HIV-1 infection." J Exp Med 206(6): 12731289.

33. Song, H., J. W. Pavlicek, F. Cai, T. Bhattacharya, H. Li, S. S. Iyer, K. J. Bar, J. M. Decker, N. Goonetilleke, M. 
K. Liu, A. Berg, B. Hora, M. S. Drinker, J. Eudailey, J. Pickeral, M. A. Moody, G. Ferrari, A. McMichael, A. S. Perelson, G. M. Shaw, B. H. Hahn, B. F. Haynes and F. Gao (2012). "Impact of immune escape mutations on HIV-1 fitness in the context of the cognate transmitted/founder genome." Retrovirology 9:89.

34. Travers, S. A., M. J. O'Connell, G. P. McCormack and J. O. McInerney (2005). "Evidence for heterogeneous selective pressures in the evolution of the env gene in different human immunodeficiency virus type 1 subtypes." J Virol 79(3): 1836-1841.

35. van Harmelen, J., C. Williamson, B. Kim, L. Morris, J. Carr, S. S. Karim and F. McCutchan (2001). "Characterization of full-length HIV type 1 subtype $\mathrm{C}$ sequences from South Africa." AIDS Res Hum Retroviruses 17(16): 1527-1531.

36. Williamson, C., L. Morris, M. F. Maughan, L. H. Ping, S. A. Dryga, R. Thomas, E. A. Reap, T. Cilliers, J. van Harmelen, A. Pascual, G. Ramjee, G. Gray, R. Johnston, S. A. Karim and R. Swanstrom (2003). "Characterization and selection of HIV-1 subtype C isolates for use in vaccine development." AIDS Res Hum Retroviruses 19(2): 133-144.

37. Yue, L., K. J. Pfafferott, J. Baalwa, K. Conrod, C. C. Dong, C. Chui, R. Rong, D. T. Claiborne, J. L. Prince, J. Tang, R. M. Ribeiro, E. Cormier, B. H. Hahn, A. S. Perelson, G. M. Shaw, E. Karita, J. Gilmour, P. Goepfert, C. A. Derdeyn, S. A. Allen, P. Borrow and
E. Hunter (2015). "Transmitted Virus Fitness and Host $\mathrm{T}$ Cell Responses Collectively Define Divergent Infection Outcomes in Two HIV-1 Recipients." PLoS Pathog 11(1): e1004565. 